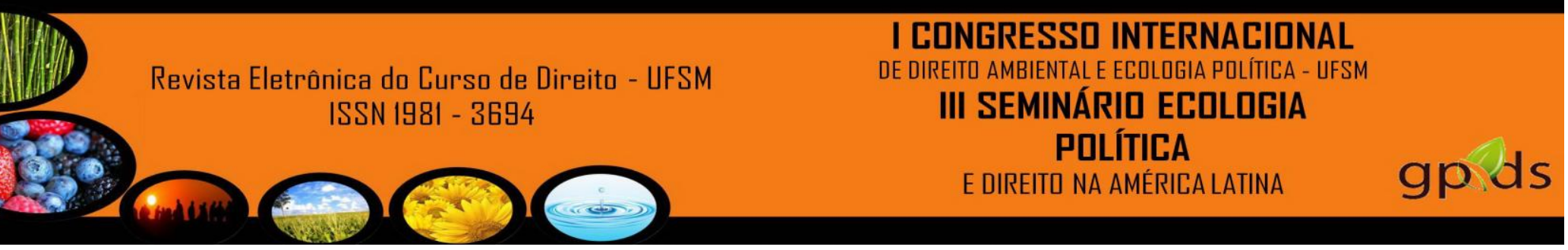

\title{
INCOMPATIBILIDADE LEGAL DE USO E OCUPAÇÃO DO SOLO A PARTIR DA APTIDÃO AGRÍCOLA: O CASO DA MICROBACIA HIDROGRÁFICA DO ARROIO MANOEL ALVES, ITAARA/RS.
}

\author{
Franciele da Silva ${ }^{1}$ \\ Leonardo Pinto dos Santos ${ }^{2}$ \\ Eliane Maria Foleto ${ }^{3}$
}

\begin{abstract}
Resumo
Esse texto visa abordar questões a respeito das áreas protegidas, sua conceituação, legislações pertinentes e um estudo de caso na microbacia hidrográfica do Arroio Manoel Alves, em Itaara, RS. É sabido que existem leis que instituem e delimitam estas áreas no território brasileiro, entretanto, não foram efetivadas conforme previsto na legislação. O estudo realizado apresenta a identificação das áreas caracterizadas como de incompatibilidade legal, ou seja, áreas que por lei são consideradas de preservação permanente, portanto de proteção integral e que atualmente são utilizadas de forma irregular para atividade agrícola e/ou de moradia. Os resultados deste estudo objetivam definir as áreas prioritárias para recuperação e conservação da microbacia, a qual é de suma importância para o município, pois, é fonte do abastecimento público de água, utilizada para agricultura, atrativo turístico da região, além da área ser tombada como Reserva da Biosfera da Mata Atlântica pela UNESCO.
\end{abstract}

Palavras-chave: Incompatibilidade Legal; Áreas Protegidas; Microbacia Hidrográfica; Itaara.

\section{INTRODUÇÃO}

A forma como ocorre o uso e a ocupação do solo no Brasil, geralmente, se faz de forma desordenada, sem haver uma estimativa prévia sobre os possíveis impactos causados aos recursos naturais e a própria ocupação. As nossas ações sobre os recursos naturais acontecem cada vez mais de forma predatória, tendo como consequência uma acentuada e acelerada degradação ambiental.

Sob essa perspectiva, a pesquisa tem como objetivo a identificação das áreas caracterizadas como incompatíveis ao que prevê a legislação, ou seja, áreas que por lei são consideradas de preservação, e que, são utilizadas de forma irregular para fins agrícolas e/ou urbanos, como ocorre na microbacia hidrográfica do Arroio Manoel Alves em Itaara, RS.

Para a caracterização da condição ambiental presente na bacia hidrográfica utilizou-se geotecnologias para elaborar o mapeamento de uso e cobertura do solo na

\footnotetext{
${ }^{1}$ Acadêmica de Geografia, Universidade Federal de Santa Maria. Contato: francieli17@gmail.com

${ }^{2}$ Acadêmico de Geografia, Universidade Federal de Santa Maria. Contato: leonardoufsm@ @otmail.com

${ }^{3}$ Doutora em Engenharia de Produção. Professora do Departamento de Geociências, Universidade Federal de Santa Maria. Contato: efoleto@gmail.com
} 
bacia, além de mapear e identificar o conflito de uso nas Áreas de Preservação Permanente (APP) ao longo da área, levando em consideração a Legislação Ambiental, que estabelece parâmetros, definições e limites referentes a ocupação e uso do solo, subsidiando dessa forma, posteriores ações que levem ações de recuperação e o monitoramento ambiental dessas áreas.

\section{ÁREAS PROTEGIDAS}

A intensa utilização dos recursos naturais pelo homem passa a exigir a adoção de medidas de proteção das áreas naturais para garantir a continuidade dos serviços ambientais prestados à qualidade de vida da sociedade. Este pressuposto é o ponto de partida para a discussão e implantação das primeiras áreas protegidas a nível mundial.

Para Ramos et al (2003), desde a criação do primeiro parque nacional do mundo, o de Yellowstone, a delimitação de espaços territoriais especialmente protegidos tem sido utilizada como estratégia de conservação da natureza.

No Brasil, na Constituição Republicana de 1934, pela primeira vez, a proteção da natureza figurou como um princípio fundamental. No seu Capítulo I (art. 10) foi definido como responsabilidade da União "proteger belezas naturais e monumentos de valor histórico e artístico". Desta forma, a Constituição passou a considerar a natureza como patrimônio nacional a ser preservado, Medeiros (2005).

A conservação de espaços naturais é uma relevante estratégia do poder público no controle e gerenciamento dos recursos ambientais. A Política Nacional do Meio Ambiente, instituída pela Lei $n^{\circ}$ 6.936/1981, evidencia a criação dessas áreas como um de seus principais instrumentos (BRASIL, 1981).

A Constituição Federal do Brasil, de 1988, consolida a preocupação internacional com a questão ambiental através das disposições do art. 225 onde são apontados os mecanismos para assegurar a universalidade de acesso à qualidade ambiental. Quanto às áreas naturais protegidas, o inciso III, do parágrafo $1^{\circ}$ do art. 225 lança as bases para a criação de espaços especialmente protegidos ao apontar a necessidade de:

III - definir, em todas as unidades da Federação, espaços territoriais e seus componentes a serem especialmente protegidos, sendo a alteração e a supressão permitidas somente através de lei, vedada qualquer utilização que 
III SEMINÁRII ECOLOGIA

PDLÍTICA

E DIREITO NA AMÉRICA LATINA

comprometa a integridade dos atributos que justifiquem sua proteção. (BRASIL, 1988, s/p).

O conceito de áreas protegidas é abrangente, integrando diferentes tipologias, como as Áreas de Preservação Permanente e a Reserva Legal, previstas pelo Código Florestal Brasileiro (Lei n 4.771/1965), e as Unidades de Conservação (UCs), definidas pelo Sistema Nacional de Unidades de Conservação da Natureza (SNUC, Lei $\mathrm{n}^{\circ}$ 9.985/2000). De tal modo, utilizamos a conceituação da União Mundial para a Natureza (The World Conservation Union - IUCN), pois define área protegida como:

Uma superfície de terra ou mar especialmente consagrada à proteção e preservação da diversidade biológica, assim como dos recursos naturais e culturais associados, e gerenciada através de meios legais ou outros meios eficazes (SCHERL, 2006, p. 7).

\section{As Áreas de Preservação Permanente}

As Áreas de Preservação Permanente (APP), em um primeiro momento, no texto original do Código Florestal de 1965, art. $2^{\circ}$ estabelecia-se como APP uma faixa marginal mínima de 5 metros para a proteção das margens de cursos d'água de até 10 metros de largura, independentemente se a área fosse urbana ou rural.

Em 1989, o Código Florestal passou por modificações, sendo significativa a mudança introduzida pela Lei $n^{\circ} 7.803 / 1989$, a qual prevê novas faixas e parâmetros diferenciados para as APPs, de acordo com a característica de cada área a ser protegida, considerando não apenas a conservação da vegetação, mas também as dimensões dos cursos d'água, independente de estar em área rural ou urbana.

O Código Florestal $\left(\operatorname{art} .2^{\circ}\right.$ ) estabelece como APPs, as florestas e demais formas de vegetação natural localizadas:

a) ao longo dos rios ou de qualquer curso d'água desde o seu nível mais alto em faixa marginal cuja largura mínima será:

1 - de 30 metros para os cursos d'água de menos de 10 metros de largura;

2 - de 50 metros para os cursos d'água que tenham de 10 a 50 metros de largura;

3 - de 100 metros para os cursos d'água que tenham de 50 a 200 metros de largura;

4 - de 200 metros para os cursos d'água que tenham de 200 a 600 metros de largura;

5 - de 500 metros para os cursos d'água que tenham largura superior a 600 metros;

b) ao redor das lagoas, lagos ou reservatórios d'água naturais ou artificiais; 
c) nas nascentes, ainda que intermitentes e nos chamados "olhos d'água", qualquer que seja a sua situação topográfica, num raio mínimo de 50 metros de largura;

d) no topo de morros, montes, montanhas e serras;

e) nas encostas ou partes destas, com declividade superior a $45^{\circ}$, equivalente a $100 \%$ na linha de maior declive;

f) nas restingas, como fixadoras de dunas ou estabilizadoras de mangues; g) nas bordas dos tabuleiros ou chapadas, a partir da linha de ruptura do relevo, em faixa nunca inferior a 100 metros em projeções horizontais; h) em altitude superior a 1.800 metros, qualquer que seja a vegetação.

O conceito legal de APP relaciona tais áreas, independente da cobertura vegetal, com a função ambiental de preservar os recursos hídricos, a paisagem, a estabilidade geológica, a biodiversidade, o fluxo gênico de fauna e flora, proteger o solo e assegurar o bem-estar das populações humanas.

As Áreas de Preservação Permanente, além das funções ambientais citadas, possuem importância ecológica por funcionarem como filtros, retendo defensivos agrícolas, poluentes e sedimentos que seriam transportados indiscriminadamente para os cursos d'água, afetando diretamente a quantidade e a qualidade desse recurso e consequentemente a fauna aquática e a população humana. Atuar como corredores ecológicos, ligando fragmentos florestais e, portanto, facilitando o deslocamento da fauna e o fluxo gênico entre as populações de espécies animais e vegetais. Além de atuar como protetoras do solo, contra os processos erosivos em regiões com topografia acidentada, as florestas ciliares continuam sendo eliminadas, cedendo lugar para a especulação imobiliária e principalmente a ocupação irregular, para a construção de moradias irregulares, para a agricultura e a pecuária e, na maioria dos casos, sendo transformadas apenas em áreas degradadas, sem qualquer tipo de produção que tenha o compromisso com a sustentabilidade.

Como podemos observar, as funções das APPs ultrapassam as barreiras de preservar a vegetação ou a biodiversidade, passando a atribuir uma função ambiental muito mais abrangente, voltada, até mesmo, a proteger espaços de relevante importância para a conservação da qualidade ambiental como a estabilidade geológica, a proteção do solo e assim assegurar o bem estar das populações humanas.

A preservação das matas ciliares em APP, evita o aceleramento de processos erosivos, do assoreamento de rios e de movimentos de massa, além de uma importante função: os corredores de biodiversidade. Segundo Lima e Zakia, (2000), a presença de mata ciliar contribui para diminuir a ocorrência do escoamento superficial, que pode 

III SEMINÁRII ECDLOGIA

POLÍTICA

E DIREITO NA AMÉRICA LATINA

Figura 02 - Mapa de situação do município de Itaara em relação ao Rio Grande do Sul.

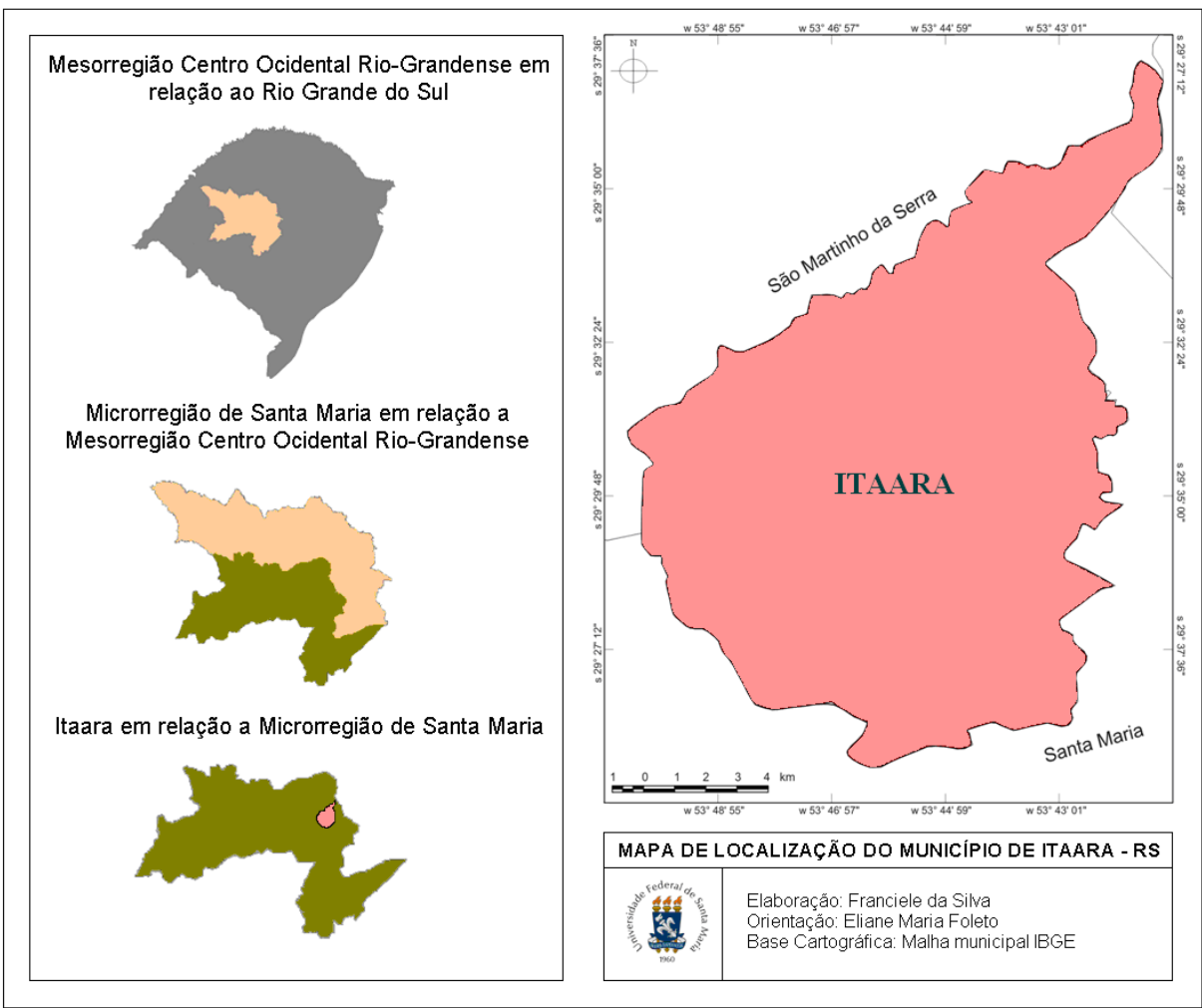

A formação territorial ${ }^{5}$ do município de Itaara ocorre com a emancipação a partir do município de Santa Maria em 28 de dezembro de 1995, através do Decreto Estadual $\mathrm{n}^{\circ} 10.643$, sendo sua instalação oficial em $1^{\circ}$ de janeiro de 1997 . De acordo com o Censo de 2010 (IBGE), Itaara apresenta uma população de 5.011 habitantes.

Com o predomínio do desenvolvimento de atividades agrícolas, o município apresenta nesta atividade a base da economia, o que implica em uma dependência dos recursos naturais. Destaca-se o recente crescimento da atividade de turismo de lazer relacionado aos espaços onde os recursos naturais apresentam-se preservados, dispostos principalmente na porção sul do município.

A microbacia hidrográfica do Arroio Manoel Alves compreende uma área de $3.173,47^{6}$ hectares situados na porção central do município de Itaara.

Figura 03 - Mapa base da mirobacia hidrográfica do Arroio Manoel Alves

\footnotetext{
${ }^{5}$ Segundo site da Prefeitura Municipal de Itaara. Endereço eletrônico: www.itaara.rs.gov.br e Instituto Brasileiro de Geografia e Estatística (IBGE).

${ }^{6}$ Cálculo feito através do software SPRING 5.0.6
} 
III SEMINÁRII ECOLOGIA

PDLÍTICA

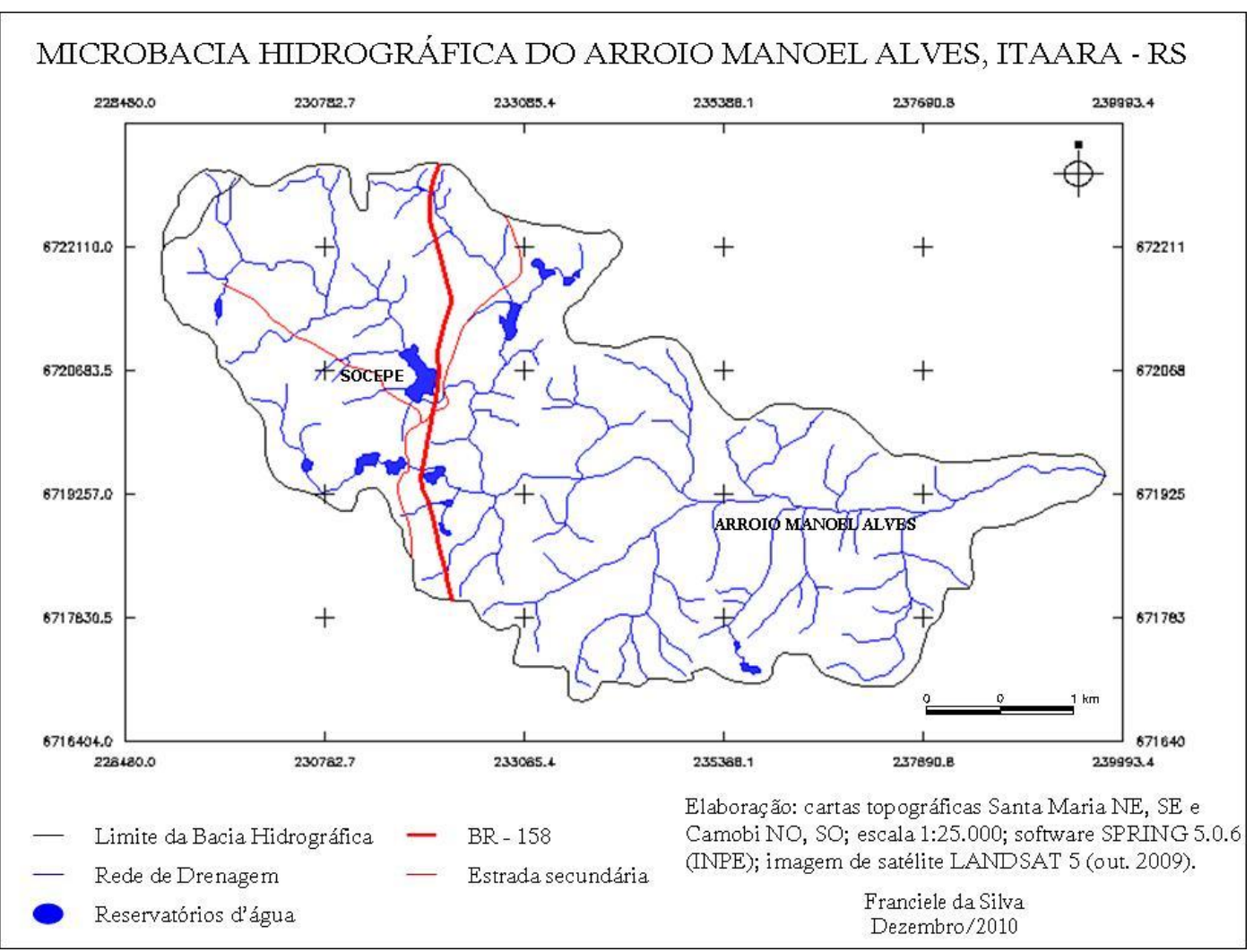

Paro estudo das áreas de preservação permanente na microbacia foram realizadas saídas a campo, com apoio da Fundação Mo ãa, com o intuito de compreender a realidade do local, bem como mapeamentos, onde se utilizou as cartas topográficas ${ }^{7}$ de Santa Maria NE, SE e Camobi NO, SO; em escala 1:25.000. Também se utilizou uma imagem de satélite LANDSAT 5, sensor TM, bandas 3, 4 e 5, de 20 de outubro de 2009, com resolução de 30 metros. O softaware SPRING 5.0.6 (Sistema de Processamento de Imagens Georreferenciadas) ${ }^{8}$ desenvolvido pelo Instituto Nacional de Pesquisas Espaciais (INPE), foi usado para o geoprocessamento.

O georreferenciamento foi efetuado a partir da coleta de coordenadas a campo, no sistema UTM (Universal Transversa de Mercator), datum horizontal SAD 69 (South American Datum) com o uso de um aparelho receptor GPS (Sistema de Posicionamento Global).

A delimitação da área de estudo teve como base os divisores d'água da microbacia. Após iniciou-se a confecção dos mapas de drenagem, uso da terra, áreas de

\footnotetext{
${ }^{7}$ Nomenclatura das cartas topográficas: Santa Maria NE folha: SH.22-V-C-IV-1-NE; Santa Maria SE folha: SH.22-V-C-IV/1-SE; Camobi NO folha: SH.22-V-C-IV/2-NO; Camobi SO folha: SH.22-V-CIV/2-SO.

${ }^{8}$ O SPRING é um software livre e sua aquisição é feita por download via pagina da internet do Instituto Nacional de Pesquisas Espaciais.
} 


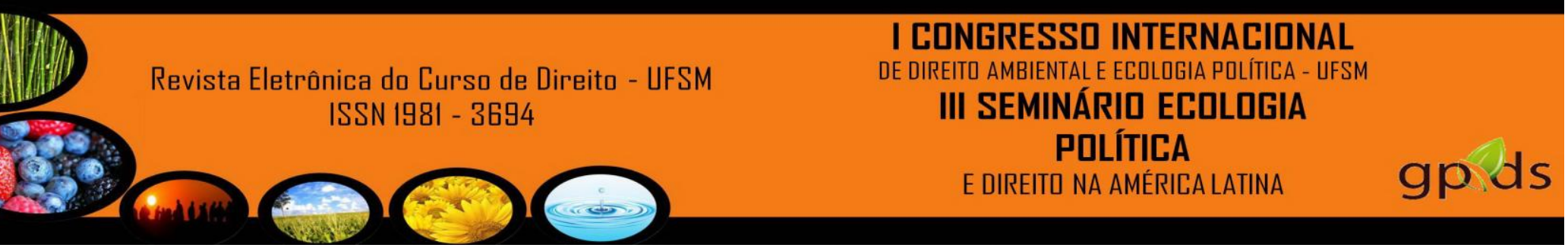

preservação permanente, hipsométrico e de declividades, que no final do processo com a combinação de informações geraram um mapa síntese das áreas de incompatibilidade legal, baseado no que é previsto pelo Código Florestal e nas resoluções do CONAMA n 302 e 303, que regulamenta as áreas de preservação permanente no entorno de reservatórios, artificiais e naturais, de água para abastecimento humano.

\section{As áreas incompatíveis na microbacia hidrográfica do Arroio Manoel Alves}

As áreas de preservação permanente ocupam uma área de 695,58 ha ou 21,91\% da área total da microbacia. Na tabela 01, destaca-se a quantificação dessas áreas.

No caso da microbacia do Arroio Manoel Alves, as APPs de margens dos cursos d'água correspondem à reserva de uma faixa de 30 metros, em rios com no máximo 10 metros de largura, a partir da cota de maior inundação, contendo ou não matas ciliares. Já as de nascentes constam de um raio mínimo de 50 metros no entorno das mesmas, com ou sem áreas vegetadas, como forma de proteger a água.

Tabela 01 - Quantificação das áreas de preservação permanente na microbacia hidrográfica do Arroio Manoel Alves/Itaara/RS

\begin{tabular}{|lrr|} 
Classes & Área (ha) & Área (\%) \\
\hline Margens & 504,16 & 72,48 \\
\hline Nascentes & 62,14 & 8,93 \\
\hline Reservatórios & 40,07 & 5,76 \\
\hline Declividade maior que $45^{\circ}$ & 89,21 & 12,83 \\
\hline Total & $\mathbf{6 9 5 , 5 8}$ & $\mathbf{2 1 , 9 1 \%}$
\end{tabular}

Fonte: Mapeamento Franciele da Silva

Organização: Franciele da Silva

A delimitação das áreas de incompatibilidade legal foi realizada onde a ocupação urbana e/ou agrícola apresentou-se inadequada com o que é previsto em lei. A sobreposição de informações do uso da terra com as Áreas de Preservação Permanente possibilitou a identificação de incompatibilidades, obtendo-se o valor de 198,93 ha ou $28,60 \%$ Da área mapeada. 
III SEMINÁRII ECDLOGIA

\section{POLÍTICA}

E DIREITO NA AMÉRICA LATINA

Tabela 02 - Combinação dos planos de informação: uso da terra x áreas de preservação permanente

\begin{tabular}{|l|r|r|r|}
\hline Classes & $\begin{array}{r}\text { Total de área da classe } \\
\text { na bacia hidrográfica } \\
\text { (ha) }\end{array}$ & $\begin{array}{r}\text { Total de APP (ha) em } \\
\text { áreas incompatíveis }\end{array}$ & $\begin{array}{r}\text { (\%) áreas } \\
\text { incompatíveis }\end{array}$ \\
\hline Margens & 504,16 & 148,41 & 29,43 \\
\hline Nascentes & 62,14 & 32,06 & 51,59 \\
\hline Reservatórios & 40,07 & 16,64 & 41,52 \\
\hline Declividade $>45^{\circ}$ & 89,21 & 1,82 & 2,04 \\
\hline Total & $\mathbf{6 9 5 , 5 8}$ & $\mathbf{1 9 8 , 9 3}$ & $\mathbf{2 8 , 6 0}$
\end{tabular}

Fonte: Mapeamento Franciele da Silva

Organização: Franciele da Silva

Pela análise da tabela 02, observa-se que as áreas de maior conflito concentramse no entorno das nascentes e dos reservatórios.

Figura 04: Mapa das áreas de incompatibilidade legal de uso e ocupação da terra na microbacia hidrográfica do Arroio Manoel Alves, Itaara - RS.

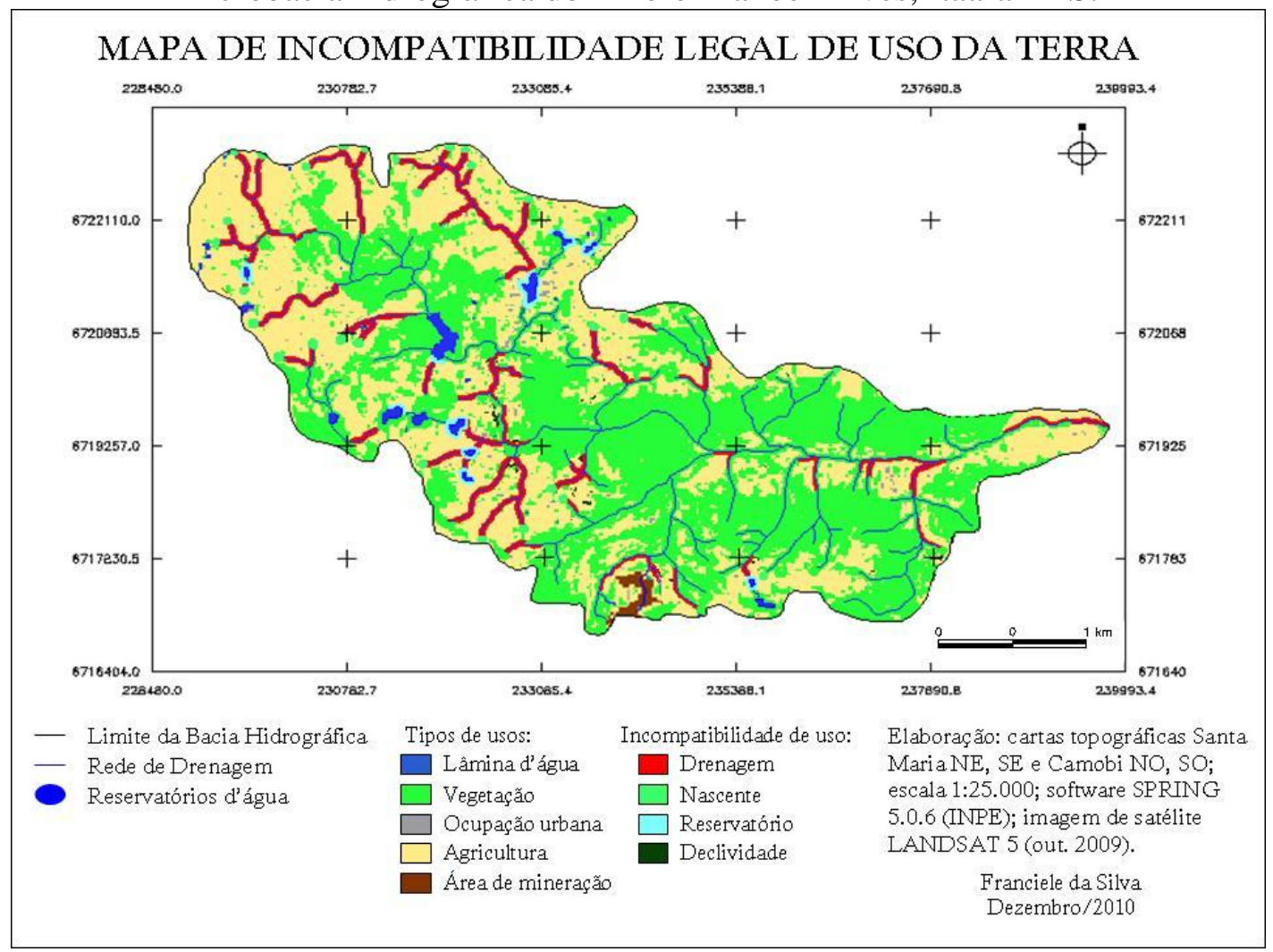

A área que corresponde ao raio de 50 metros no entorno das nascentes, considerada APP, abrange 62,14ha da microbacia hidrográfica. Entretanto, mais da metade $(51,59 \%)$ ocorre ocupação irregular, principalmente pelas culturas. Como pode ser observada no mapa, a atividade agrícola é a maior responsável pelas áreas 
Revista Eletrônica do Curso de Direito - UFSM

ISSN 1981 - 3694
I CDNGRESSO INTERNACIDNAL

DE DIREITO AMBIENTAL E ECDLOLIA PDLIITICA - UFSM

III SEMINÁRII ECDLOGIA

POLÍTICA

E DIREITO NA AMÉRICA LATINA

incompatíveis. Neste contexto, destaca-se na figura 05, uma nascente localizada próxima à cultura de soja, possibilitando a contaminação do curso d'água por produtos químicos, como agrotóxicos e fertilizantes químicos. Na figura 06 observa-se a incompatibilidade legal no decorrer do curso d'água, com cultivo de soja praticamente dentro do Arroio.

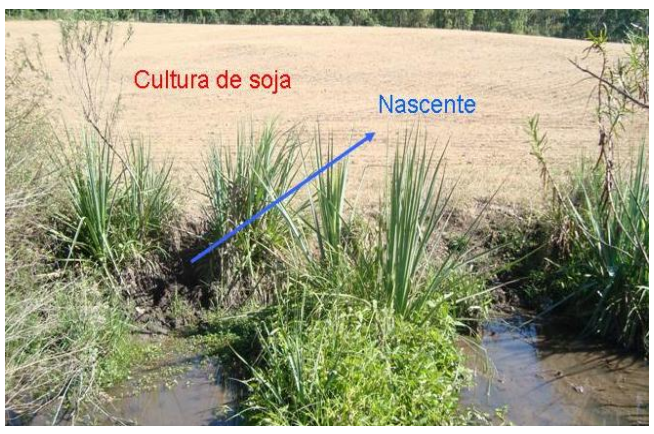

Figura 05: Nascente próxima à cultura de soja. Fonte: Trabalho de campo, Dez. 2011.

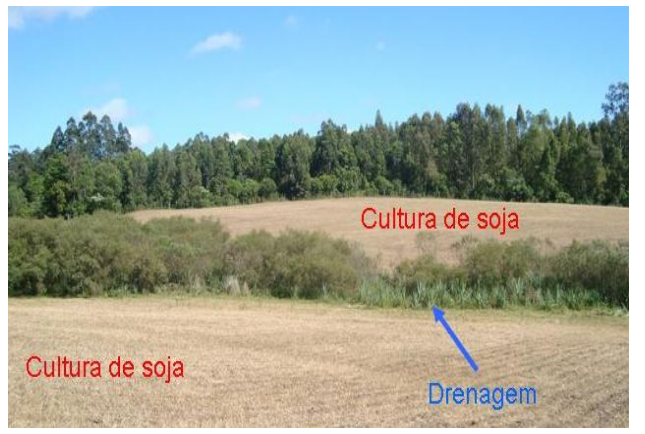

Figura 06: Drenagem próxima à cultura de soja Fonte: Trabalho de campo, Dez. 2011

\section{CONSIDERAÇÕES FINAIS}

A identificação e análise sobre as condições ambientais presentes na microbacia hidrográfica do Arroio Manoel Alves são importantes para espacializar às áreas a serem recuperadas, evitando que os problemas diagnosticados como a ocupação das áreas de preservação permanente, prejudiquem ainda mais o aspecto qualiquantitativo da água e, consequentemente impossibilitando futuramente os usos da água, principalmente para o abastecimento humano, único manancial disponível e, uso para recreação, sendo que os balneários e a beleza cênica representam um atrativo turístico para o município.

O mapeamento das áreas de incompatibilidade legal, especializa as áreas ocupadas/degradadas e possibilita priorizar estas áreas em projetos de recuperação.

A recuperação de áreas degradadas é uma prática muito importante no contexto atual, visto que muitos desastres ambientais estão acontecendo, justamente pelo uso e ocupação das áreas que deveriam ser preservadas, atualmente vários mecanismos estão sendo estudados, como o Pagamento por Serviços ambientais, com a perspectiva de incentivar os proprietários a manter as APP conservadas e quando degradadas recuperálas. Apontar possibilidades para a recuperação dessas áreas é importante tanto para 


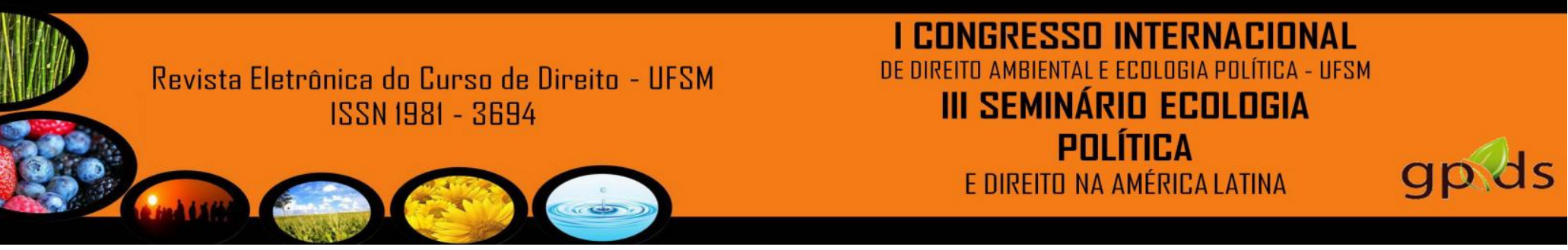

garantir a manutenção das atividades econômica, quanto para o equilíbrio ecológico do local.

\section{REFERÊNCIAS}

BRASIL. Lei n. 4.771, de 15 de setembro de 1965. Institui o novo Código Florestal. Presidência da República, Casa Civil, Brasília, DF, 15 set. 1965. Disponível em: <http://www.planalto.gov.br/ccivil_03/LEIS/L4771.htm> Acesso em: 14 set. 2010.

. Lei no 6.766, de 19 de dezembro de 1979. Dispõe sobre o Parcelamento do Solo Urbano e dá outras Providências. Presidência da República, Casa Civil, Brasília, DF, 19 dez. 1979. Disponível em: 〈http://www.planalto.gov.br/ccivil/LEIS/L6766.htm> Acesso em: 15 jun. 2010.

Constituição da República Federativa da Brasil de 1988. Presidência da República, Casa Civil, Brasília, DF, 5 out. 1988. Disponível em: <http://www.planalto.gov.br/ccivil_03/constituicao/constitui\%C3\%A7ao.htm> Acesso em: 25 jun. 2010.

Lei n. 9.985, de 18 de julho de 2000. Institui o Sistema Nacional de Unidades de Conservação da Natureza. Presidência da República, Casa Civil, Brasília, DF, 18 jul. 2000. Disponível em: <http://www.planalto.gov.br/ccivil_03/LEIS/L9985.htm> Acesso em: 5 ag. 2010.

CONSELHO NACIONAL RESERVA DA BIOSFERA DA MATA ATLÂNTICA Conselho Nacional da Reserva da Biosfera da Mata Atlântica. São Paulo, 2004. Disponível em: <http://www.rbma.org.br/default_02.asp> Acesso em: 2 set. 2010.

FUNDAÇÃO ESTADUAL DE PROTEÇÃO AMBIENTAL HENRIQUE LUIZ ROESSLER/RS - Fundação Estadual de Proteção Ambiental Henrique Luiz Roesler. Porto Alegre, 2002. Disponível em: <http://www.fepam.rs.gov.br/> Acesso: 07 jul. 2010.

LIMA, W. P.; ZAKIA, M. J. B. Hidrologia de Matas Ciliares. In: RODRIGUES, R. R.; LEITÃO-FILHO, H. F. Matas Ciliares: conservação e recuperação. São Paulo: Ed. da Universidade de São Paulo, 2001 - 2a ed., p 33-44.

MEDEIROS, R.. Evolução das tipologias e categorias de Áreas Protegidas no Brasil. Ambiente \& Sociedade, Campinas, n. 1, jan./jun., p. 41-64, 2006. Disponível em: <http://www.scielo.br/pdf/asoc/v9n1/a03v9n1.pdf>. Acesso em: 17 abr. 2011.

ORGANIZAÇÃO DAS NAÇÕES UNIDAS PARA A EDUCAÇÃO A CIÊNCIA E A CULTURA - UNESCO. Subsídios ao zoneamento da APA Gama-Cabeça de Veado e Reserva da Biosfera do Cerrado: caracterização e conflitos socioambientais. Brasília, DF: UNESCO, 2003. 176 p. Disponível em: 


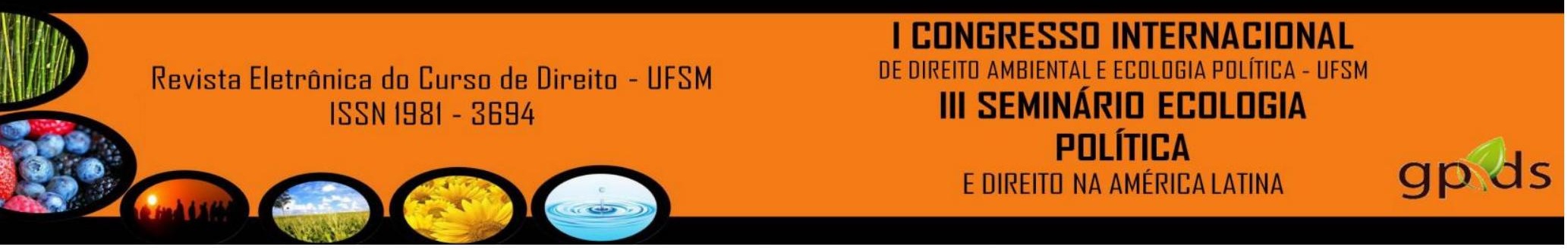

<http://unesdoc.unesco.org/images/0013/001303/130301por.pdf> Acesso em: 23 out. 2010.

RAMOS, A. C. B. et al. Mecanismos de proteção ambiental em áreas particulares. In: LITTLE, P. E. (Org.). Políticas ambientais no Brasil: Análises, instrumentos e experiências. São Paulo: Peirópolis, 2003.

ROCHA, J. S. M. Manual de projetos ambientais. Santa Maria: Imprensa Universitária, 1997. 423p.

SCHERL, L. M., et al. As áreas protegidas podem contribuir para a redução da pobreza? Oportunidades e limitações. Reino Unido: IUCN, 2006. 60 p. 